\title{
POTENSI SHALE HYDROCARBON FORMASI BROWN SHALE, CEKUNGAN SUMATRA TENGAH BERDASARKAN DATA LOG MEKANIK
}

\author{
Sugeng Widada ${ }^{1)}$, Salatun Said ${ }^{2)}$, Hendaryono ${ }^{3)}$ dan Listriyanto ${ }^{4)}$ \\ 1,2,3) Jurusan Teknik Geologi, Fakultas Teknologi Mineral, UPN "Veteran" Yogyakarta \\ $\left.{ }^{4}\right)$ Program Studi Teknik Perminyakan, Fakultas Teknik, Universitas Proklamasi 45 Yogyakarta \\ Coresponding author.email: swgeoupn@yahoo.co.id
}

\begin{abstract}
Abstrak
Formasi Brown Shale merupakan batuan induk utama hidrokarbon di Cekungan Sumatra Tengah. Penelitian ini bertujuan mengevaluasi potensi formasi tersebut sebagai batuan induk hidrokarbon dan implikasinya dalam eksplorasi shale hydrocarbon berdasarkan data wireline log. Evaluasi yang dilakukan meliputi penentuan ona prospek (shale play), evaluasi kandungan material organik (TOC) untuk mengetahui tingkat kekayaan batuan induk dan evaluasi tingkat kematangannya. Tiga sumur, Sumur Gamma, Jeta dan Kilo dievaluasi dengan menggunakan Metoda Passey (1990) dan Bowman (2010) . Log Gamma Ray, Resistivitas, Sonic, Netron dan Densitas digunakan dalam studi ini.

Dari hasil analisis menunjukkan Formasi Brown Shale yang tertembus oleh ketiga sumur tersebut tersusun oleh perselingan batulempung dan batulanau yang mengindikasikan mempunyai prospek sebagai batuan induk dengan tingkat kekayaan material organik miskin sampai kaya dan telah mencapai tingkat kematangan hidrokarbon. Kandungan TOC pada Sumur Gamma berkisar antara 2-8\%(kaya) dan tingkat kematangan minyak dicapai pada kedalaman 6550 ft. Kandungan TOC pada Sumur Jeta berkisar antara 0-7\%(miskin-kaya) dan tingkat kematangan minyak dicapai pada kedalaman $8550 \mathrm{ft}$. Kandungan TOC pada Sumur Kilo berkisar antara 0-9\%(miskin-kaya) dan tingkat kematangan minyak dicapai pada kedalaman $8100 \mathrm{ft}$.

Berdasarkan hasil tersebut menunjukkan Formasi Brown Shale yang tertembus oleh ketiga sumur di daerah telitian mempunyai potensi yang baik sebagai batuan induk hidrokarbon dan shale hidrokarbon.

Kata kunci : Formasi Brown Shale, Metoda Passey, Batuan induk migas dan shalehydrocarbon
\end{abstract}

\section{Pendahuluan}

Hingga saat ini minyak dan gas bumi masih merupakan sumber energi utama di muka bumi ini. Seiring dengan perkembangan waktu, jumlah cadangan sumber energi tersebut semakin menipis. Padahal dengan kemajuan industri dan meningkatnya jumlah kendaraan bermotor akan meningkatkan konsumsi migas. Oleh karena itu, kegiatan eksplorasi geologi untuk menemukan lapangan-lapangan migas baru terus ditingkatkan oleh Pemerintah Indonesia.

Shale hydrocarbon termasuk salah satu sumber energi yang pada saat ini mulai banyak diburu oleh para eksplorasionist untuk mendapatkan cadangan migas baru. Amerika Serikat termasuk pionir dalam pengembangan eksplorasi dan eksploitas shale hydrocarbon. Beberapa lapangan shale gas dengan cadangan mencapai ratusan TCF, seperti Lapangan Barnett dan Bakken, berhasil dikembangkan di negara tersebut.

Dengan kondisi geologinya, Indonesia juga diyakini merupakan salah satu wilayah yang mempunyai potensi cadangan shale hydrocarbon. Cekungan Sumatra Tengah merupakan salah satu cekungan yang diyakini mempunyai potensi shale hydrocarbon yang potensial. Di cekungan tersebut, Formasi Brown Shale yang tersusun oleh sedimen lakustrin, merupakan target utama dalam eksplorasi shale hydrocarbon. Bukti yang menunjukkan bahwa sebagian besar migas yang diproduksi dari lapangan-lapangan migas di Cekungan Sumatra Tengah berasal dari Formasi Brown Shale, memperkuat keyakinan formasi tersebut mempunyai potensi yang baik sebagai batuan induk maupun reservoar shale hydrocarbon.

Penelitian ini dilakukan dengan tujuan mengevaluasi potensi Formasi Brown Shale sebagai batuan induk dan reservoar shale hydrocarbon. Analisis dilakukan dengan cara mengidentifikasi litologi penyusun formasi tersebut, tingkat kekayaan material organik (TOC - total organic carbon) serta tingkat kematangannya berdasarkan data log mekanik. Tiga sumur yang menembus Formasi Brown Shale, Sumur Gamma, Jeta dan Kilo, digunakan dalam penelitian ini. 


\section{POTENSI SHALE HYDROCARBON FORMASI BROWN SHALE, CEKUNGAN SUMATRA TENGAH BERDASARKAN DATA LOG MEKANIK}

Secara geologis, lokasi penelitian terletak di Cekungan Sumatra Tengah (Gambar 1). Secara stratigrafis Formasi Brown Shale merupakan penyusun Kelompok Pematang yang terendapkan di lingkungan lakustrin pada saat terjadi rifting pada Kala Eosen - Oligosen (Gambar 2). Formasi ini secara selaras diendapkan di atas Formasi Lower Red Bed dan secara selaras ditutupi oleh Formasi Upper Red Bed.

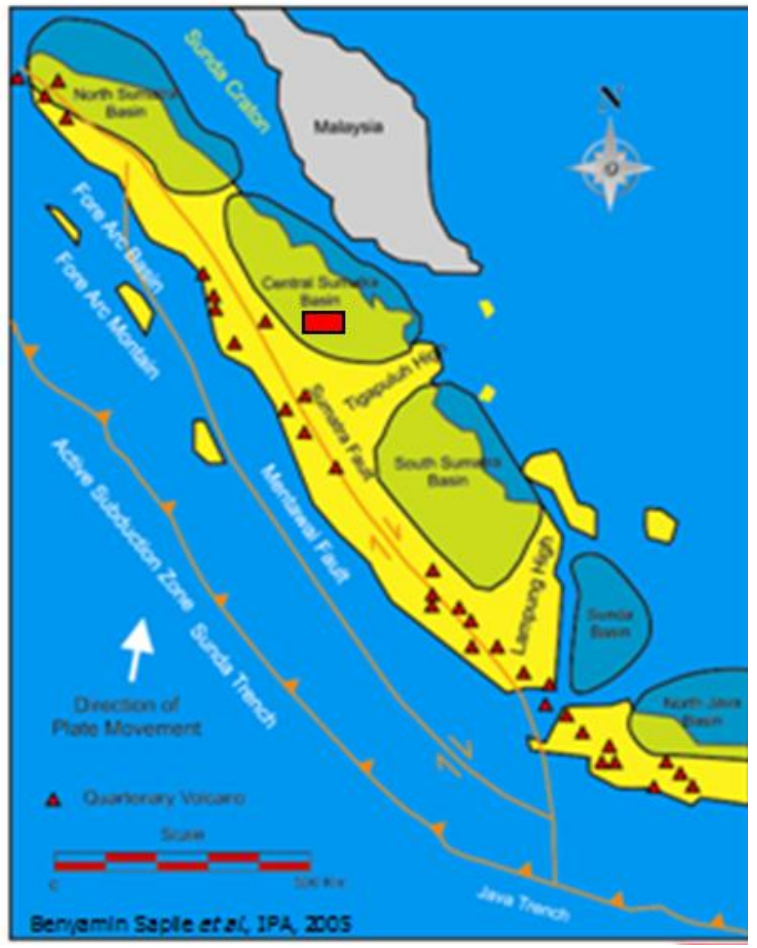

Gambar 1. Lokasi Daerah Penelitian

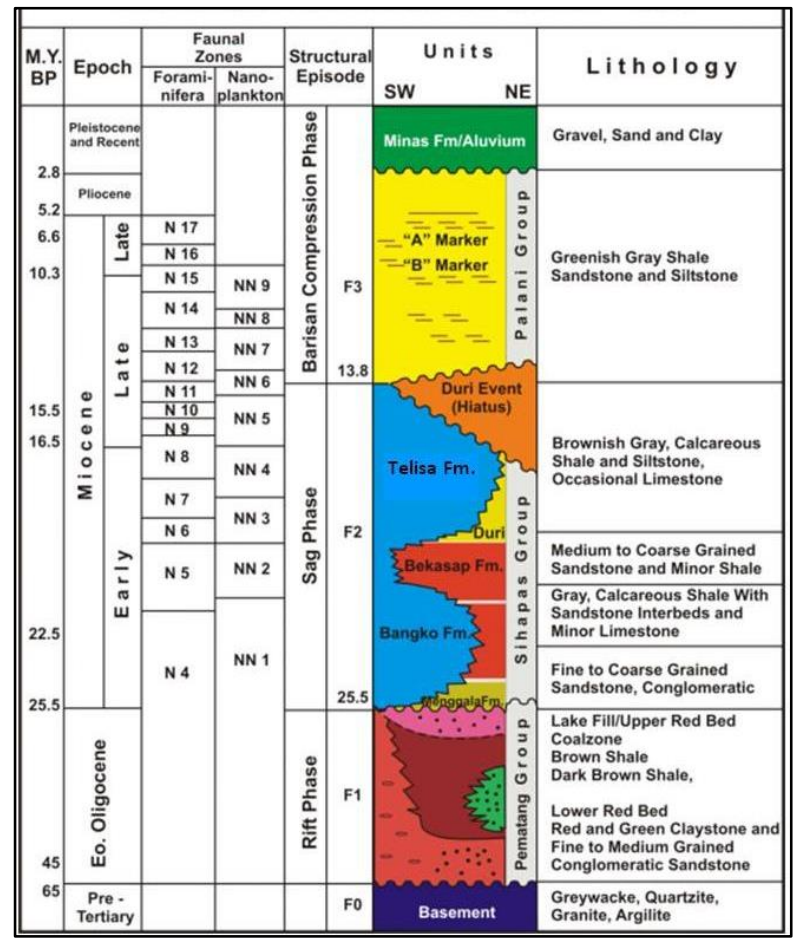

Gambar 2. Stratigrafi Regional Cekungan Sumatra Tengah (Heidrick, \& Aulia, 1993) 


\section{Metodologi}

Metode yang umum digunakan dalam mengevaluasi kekayaan dan tingkat kematangan suatu batuan induk adalah berdasarkan hasil analisis laboratorium (seperti : analisis TOC, pirolisa, analisis unsur, reflektivitas vitrinite, indeks alterasi termal, gas chromatografi, dan deskripsi visual kerogen). Kendala yang sering dijumpai dalam pekerjaan eksplorasi migas adalah jarangnya sumur yang mempunyai data geokimia dari hasil analisis laboratorium. Dalam penelitian ini evaluasi potensi Formasi Brown Shale sebagai batuan induk dilakukan berdasarkan data log mekanik dengan menggunakan Metoda Passey (1990) dan Metoda Bowman (2010) . Jenis-jenis log yang digunakan dalam penelitian ini antara lain log gamma ray, log resistivitas, log sonik, log densitas dan log netron.

Untuk mengetahui potensi Formasi Brown Shale sebagai batuan induk migas dan reservoar shale hydrocarbon, maka dilakukan beberapa analisis antara lain : identifikasi litologi penyusun, evaluasi tingkat kematangan dan evaluasi tingkat kekayaan (kandungan TOC). Adapun metoda evaluasi dijelaskan sebagai berikut :

\section{Identifikasi Litologi}

Batuan induk utama yang menggenerasikan migas adalah serpih dan batulempung gampingan. Salah satu syarat untuk dapat menjadi batuan induk adalah batuan tersebut harus mempunyai kandungan material organik dalam jumlah yang signifikan ( $>1 \%$ berat). Secara teoritis, batuan induk yang kaya material organik tersusun oleh 3 komponen, yaitu matriks batuan, material organik padat dan fluida yang mengisi spasi pori. Batuan non-induk hanya terdiri dari 2 komponen, yaitu matriks batuan dan fluida yang mengisi spasi pori.Keberadaan serpih kaya organik bisa dikenali dari data log mekanik dengan ciri sebagai berikut : nilai kurva gamma ray yang tinggi, kurva resistivitas tinggi, kurva densitas rendah, nilai porositas netron tinggi dan nilai kurva sonik tinggi.

Disamping untuk mengetahui keberadaan batuan induk potensial, identifikasi litologi penyusun Formasi Brown Shale juga bertujuan untuk mengetahui tingkat kerapuhan batuan. Sebagai reservoar serpih hidrokarbon suatu batuan harus bersifat rapuh (brittle), sehingga pori-pori dalam batuan tersebut dapat terbuka pada saat dilakukan fracturing. Salah satu ciri keberadaan formasi yang rapuh adalah formasi tersebut tersusun oleh perselang-selingan batulempung dan batulanau.

\section{Evaluasi Kematangan}

Dalam batuan induk yang belum matang, material organik padat dan matriks batuan terdiri dari fraksi padat, sementara spasi pori batuan terisi air formasi. Pada saat batuan induk mencapai kematangan, sebagian material organik padat berubah menjadi hidrokarbon cair (atau gas) yang akan bergerak menuju ruang pori dan mengusir air formasi. Dalam penelitian ini tingkat kematangan batuan induk dievaluasi berdasarkan data log mekanik dengan menggunakan Metoda Passey.

Untuk mengevaluasi kematangan batuan induk, Passey (1990) mengembangkan suatu metoda yang disebut $\Delta \log \mathrm{R}$ Technique. Teknik ini telah sukses diaplikasikan pada banyak sumur di seluruh dunia, baik pada batuan induk klastik maupun karbonat. Pada metoda ini digunakan kombinasi log resistivitas dan sonik. Log sonik merupakan tipe log mekanik yang mengukur interval waktu lewat $(\Delta \mathrm{t})$ dari suatu gelombang suara kompresional yang merambat melewati $1 \mathrm{ft}$ formasi dan dinyatakan dalam $\mu \mathrm{sec} / \mathrm{ft}$. Log resistivitas merupakan tipe log mekanik yang mengukur tahanan jenis batuan dan dinyatakan dalam satuan ohm-m.

Untuk mengetahui tingkat kematangan batuan induk, kurva interval waktu lewat dan kurva resistivitas diatur skalanya sehingga skala relativnya adalah $50 \mu \mathrm{sec} / \mathrm{ft}$ atau $164 \mu \mathrm{sec} / \mathrm{m}$ per satu siklus logaritma resistivitas. Kedua kurva tersebut kemudian ditampalkan dan sebagai garis dasar pembacaan (baseline) ditempatkan pada zona batuan berbutir halus non-source rock.Kondisibaseline dicirikan oleh berimpitnya kedua kurva satu sama lain pada kisaran kedalaman yang signifikan. Adanya separasi antara kurva resistivitas dan sonik mengindikasikan adanya interval batuan induk kaya material organik yang matang (Gambar 3). 


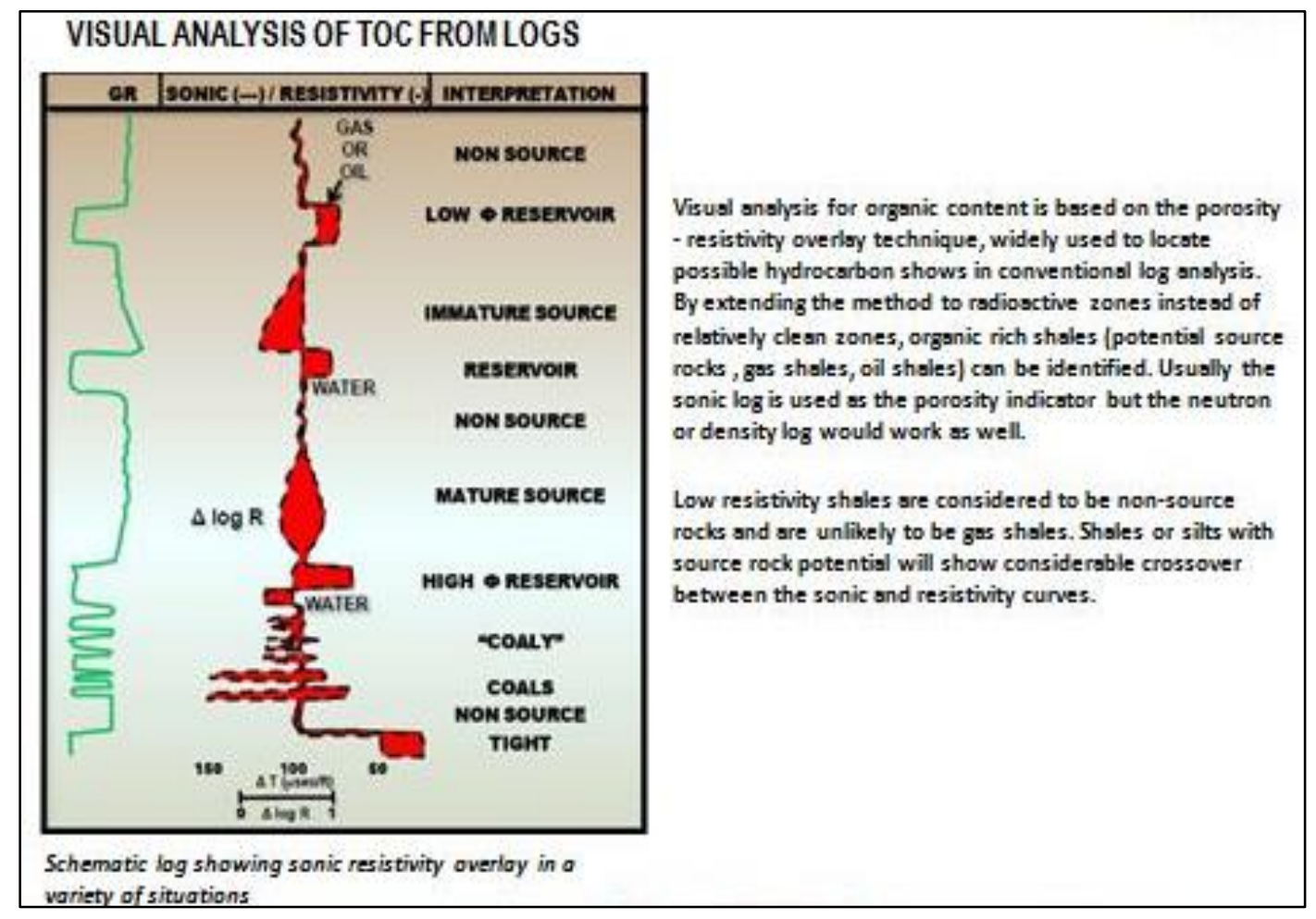

Gambar 3. Analisis Visual BatuanIndukBerdasarkan Data Log Mekanik (Passey, 1990)

\section{Evaluasi Kekayaan Material Organik (TOC)}

Separasi $\Delta \log \mathrm{R}$ berhubungan langsung dengan TOC dan merupakan fungsi kematangan. Jika nilai LOM (Level of Maturity) diketahui, maka kandungan TOC pada suatu batuan induk dapat ditentukan. Nilai LOM bisa diperoleh dari hasil analisis sampel (seperti : reflektivitas vitrinite, indeks alterasi termal atau Tmax ). Karena tidak adanya data analisis laboratorim, pada penelitian ini nilai LOM diperoleh dari harga Ro (reflektivitas vitrinite) Formasi Brown Shale dari sumur terdekat. Formula yang digunakan untuk menghitung kandungan TOC berdasarkan Metode Passey ditunjukkan pada Gambar 4 dan dijelaskan sebagai berikut :

1. $\operatorname{DlogR}=\log ($ RESD $/$ RESDbase $)+0.02 *($ DTC - DTCbase)

2. Wtoc $=\mathrm{D} \log \mathrm{R}^{*} 10^{\wedge}\left(0.297-0.1688^{*} \mathrm{LOM}\right)$

3. $\mathrm{WT} \%$ toc $=100 * \mathrm{Wtoc}$

Dimana :

RESD $=$ depth resistivity pada zona interest (ohm-m)

RESDbase $=$ baselinedepth resistivity pada zona non-source (ohm-m)
DTC $=$ nilai kurva sonik kompresional pada zona interest $(\mu \mathrm{sec} / \mathrm{ft})$

DTCbase = baseline sonik kompresional pada zona non-source ( $\mu \mathrm{sec} / \mathrm{ft})$

$\mathrm{D} \log \mathrm{R}=$ Angka Passey (fraksi)

$\mathrm{LOM}=$ level of organic maturity

Wtoc = total organic carbon (fraksi berat)

$\mathrm{WT} \%$ toc =total organic carbon (persen berat)

\section{Identifikasi Zona Prospek (Shale Play)}

Untuk mengidentifikasi keberadaan Shale Play di daerah telitian digunakan Metoda Bowman (2010). Metoda ini pada prinsipnya merupakan modifikasi Metoda $\Delta \log \mathrm{R}$ Technique yang dikembangkan oleh Passey (1990). Keberadaan zona prospek dapat ditentukan berasarkan hasil cross plot antara nilai log sonik (DT) dengan log resistivitas. Dari cross-plot tersebut dapat digunakan untuk menentukan garis serpih yang selanjutnya dapat digunakan untuk menghitung harga log sonik semu (DtR) yang bisa ditampalkan dengan kurva sonik (DT) yang sudah ada untuk menngidentifikasi keberadaan zona serpih organik potensial. 


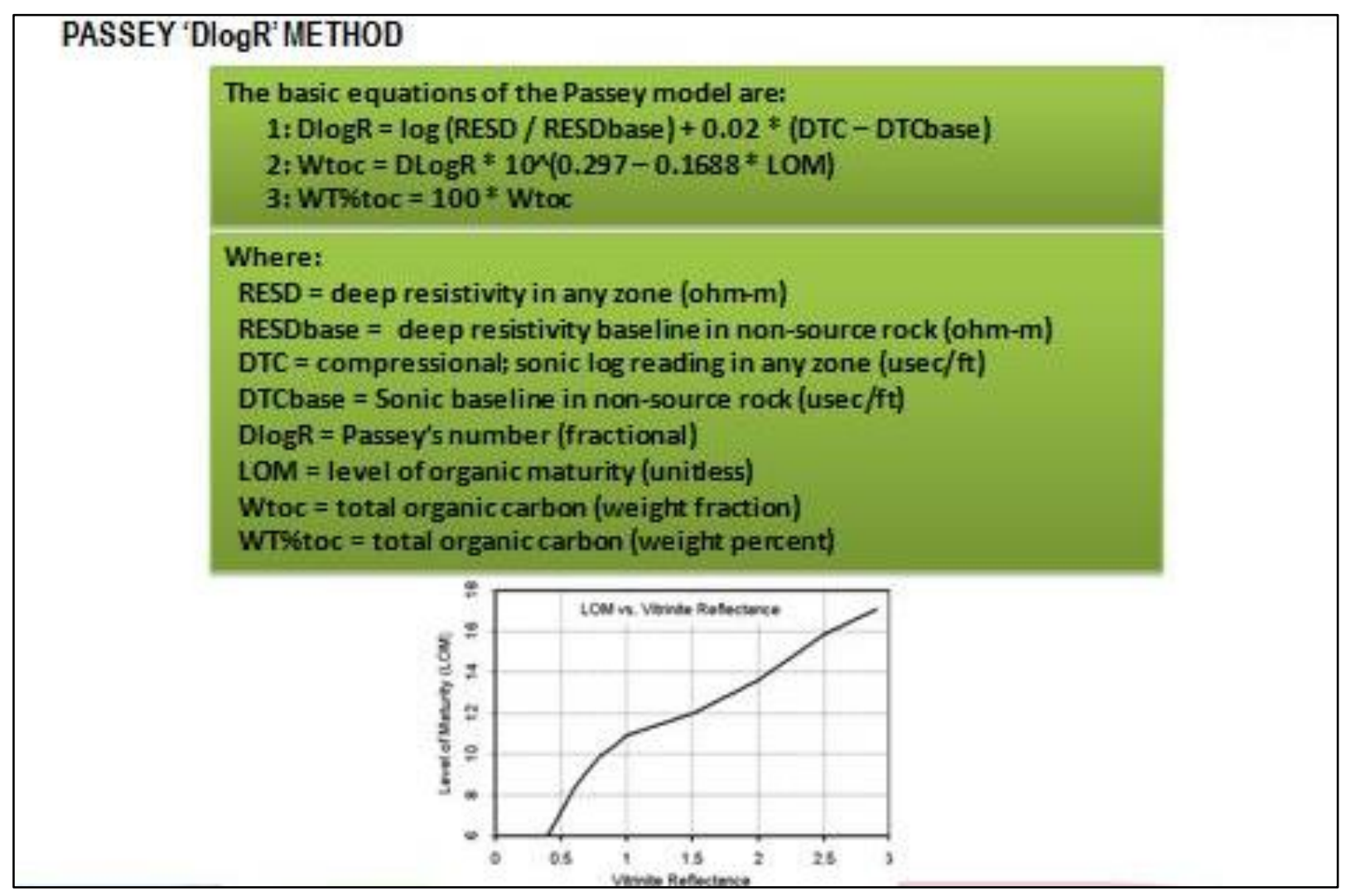

Gambar 4. Formula Perhitungan TOC Berdasarkan Data Log Mekanik

(Passey, 1990)

\section{Hasil Dan Pembahasan}

Berdasarkan data log mekanik yang tersedia, potensi Formasi Brown Shale sebagai batuan induk migas dan reservoar shale hydrocarbon yang tertembus oleh sumur-sumur di daerah telitian diuraikan sebagai berikut.

\section{Sumur Gamma}

Di dalam Sumur Gamma puncak Formasi Brown Shale ditembus pada kedalaman $6421 \mathrm{ft}$ RKB dan menerus sampai kedalaman total (8020 $\mathrm{ft}$ ) dengan ketebalan $1599 \mathrm{ft}$. Batas kontak dengan formasi di atasnya, yaitu Formasi Upper Red Bed ditandai dengan kontak erosional antara batulempung penyusun Formasi Brown Shale dengan batupasir penyusun Formasi Upper Red Bed. Dari data log menunjukkan Formasi Brown Shale terutama tersusun oleh sedimen detritus halus yaitu perselingan antara batulempung dan batulanau. Adanya perselingan batulempung dan batulanau diindikasikan dengan rekaman kurva gamma ray yang membentuk pola gergaji. Fenomena tersebut menunjukkan bahwa batuan penyusun formasi ini mempunyai sifat yang rapuh (brittle). Sifat kerapuhan merupakan salah satu sifat yang dibutuhkan oleh suatu batuan untuk menjadi reservoar shale hydrocarbon.

Dari hasil overlay antara kurva sonik dan resistivitas dengan menggunakan Metoda Passey menunjukkan hampir semua interval penyusun Formasi Brown Shale yang ditembus oleh sumur ini membentuk separasi. Hal ini mengindikasikan bahwa litologi penyusun formasi tersebut mempunyai kandungan material organik yang tinggi dan telah mencapai kematangan termal (Gambar 5). Puncak kematangan minyak Formasi Brown Shale pada Sumur Gamma diperkirakan tercapai pada kedalaman $6550 \mathrm{ft}$.Analisis kandungan TOC pada Formasi Brown Shale di Sumur Gamma menunjukkan formasi tersebut mempunyai kandungan organik yang kaya (2-8\%) (Gambar 5).

Keberadaan serpih organik yang matang pada Formasi Brown Shale dalam Sumur Gamma juga diperkuat dari hasil analisis dengn Metoda Bowman (2010). Hasil cross-plotting antara harga log sonik semu (DtR) dengan kurva log 


\section{POTENSI SHALE HYDROCARBON FORMASI BROWN SHALE, CEKUNGAN SUMATRA TENGAH BERDASARKAN DATA LOG MEKANIK}

sonik (DT) menunjukkan adanya zona prospek

(shale play) pada formasi ini (Gambar 5).

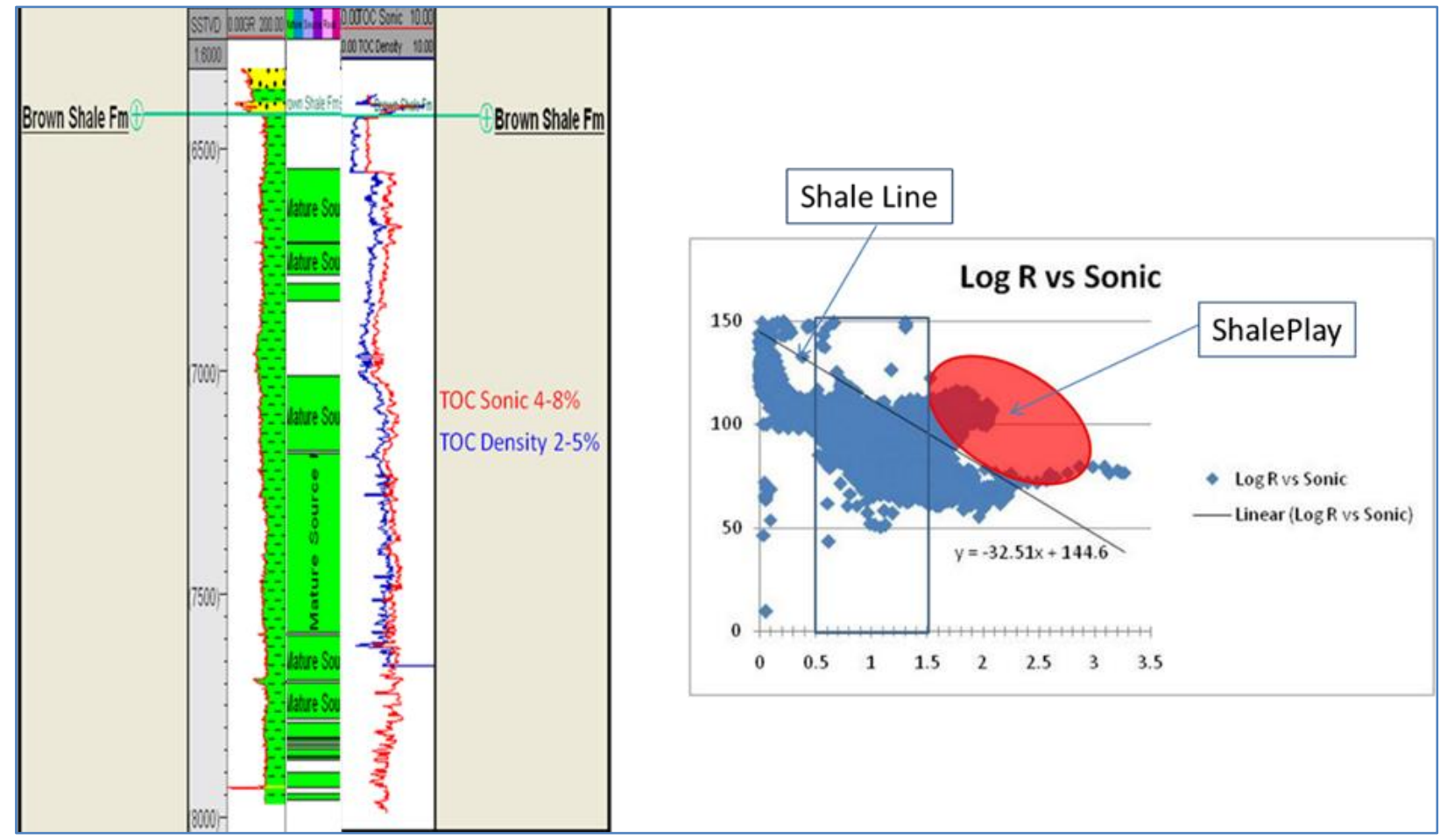

Gambar 5. Hasil Analisis Geokimia Sumur Gamma yang Menunjukan Seluruh Interval Formasi Brown Shale Tersusun oleh Litologi yang Kaya Material Organik (TOC 2-8\%) yang telah Matang

Dari uraian di atas dapat disimpulkan bahwa hampir seluruh interval penyusun Formasi Brown Shale yang ditembus Sumur Gamma mempunyai potensi baik sebagai batuan induk migas maupun reservoar shale hydrocarbon.

\section{Sumur Jeta}

Di dalam Sumur Jeta puncak Formasi Brown Shale ditembus pada kedalaman $8458 \mathrm{ft}$ RKB dan menerus sampai kedalaman total (9740 $\mathrm{ft}$ ) dengan ketebalan $1272 \mathrm{ft}$. Batas kontak dengan formasi di atasnya, yaitu Formasi Upper Red Bed ditandai dengan kontak erosional antara batulempung penyusun Formasi Brown Shale dengan batupasir penyusun Formasi Upper Red Bed. Dari data log menunjukkan Formasi Brown Shale terutama tersusun oleh sedimen detritus halus yaitu perselingan antara batulempung dan batulanau. Adanya perselingan batulempung dan batulanau diindikasikan dengan rekaman kurva gamma ray yang membentuk pola gergaji. Fenomena tersebut menunjukkan bahwa batuan penyusun formasi ini mempunyai sifat yang rapuh (brittle). Sifat kerapuhan merupakan salah satu sifat yang dibutuhkan oleh suatu batuan untuk menjadi reservoar shale hydrocarbon.

Dari hasil overlay antara kurva sonik dan resistivitas dengan menggunakan Metoda Passey menunjukkan tidak semua interval penyusun Formasi Brown Shale membentuk separasi. Kenampakan separasi hanya bisa diamati pada interval 9050 - $8458 \mathrm{ft}$. Hal ini mengindikasikan bahwa litologi penyusun formasi bagian atas sajalah yang mempunyai kandungan material organik yang tinggi dan telah mencapai kematangan termal (Gambar 6). Puncak kematangan minyak Formasi Brown Shale pada Sumur Jeta diperkirakan tercapai pada kedalaman $8550 \mathrm{ft}$. Analisis kandungan TOC pada Formasi Brown Shale di Sumur Jeta menunjukkan formasi tersebut mempunyai kandungan organik miskin - kaya (0-7\%) (Gambar 6).

Keberadaan serpih organik yang matang pada Formasi Brown Shale dalam Sumur Jeta juga diperkuat dari hasil analisis dengn Metoda Bowman (2010). Hasil cross-plotting antara harga log sonik semu (DtR) dengan kurva log sonik (DT) menunjukkan adanya zona prospek (shale play) pada formasi ini (Gambar 6). 

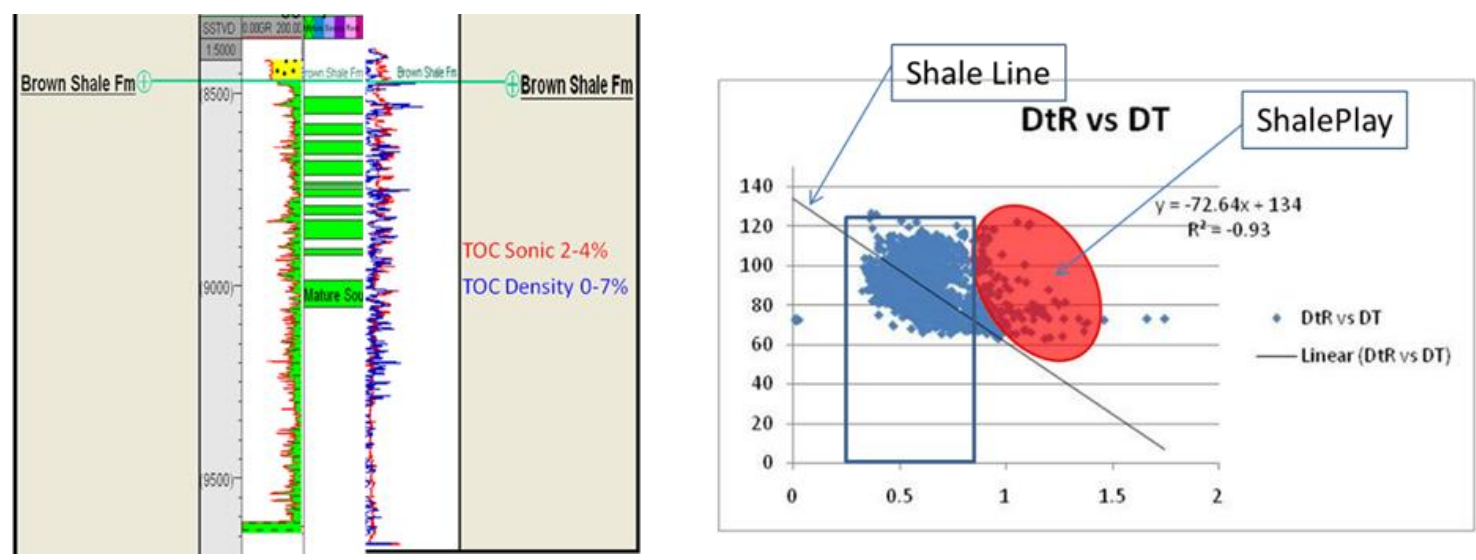

Gambar 6. Hasil Analisis Geokimia Sumur Jetta yang Menunjukan Bagian Atas Formasi Brown Shale Tersusun oleh Litologi yang Kaya Material Organik (TOC 2-7\%) yang Telah Matang

Dari uraian di atas dapat disimpulkan bahwa hanya bagian atas interval penyusun Formasi Brown Shale dalam Sumur Jeta yang mempunyai potensi baik sebagai batuan induk migas maupun reservoar shale hydrocarbon.

\section{Sumur Kilo}

Di dalam Sumur Kilo puncak Formasi Brown Shale ditembus pada kedalaman $8076 \mathrm{ft}$ RKB dan menerus sampai kedalaman total $(9190 \mathrm{ft})$ dengan ketebalan $1114 \mathrm{ft}$. Batas kontak dengan formasi di atasnya, yaitu Formasi Upper Red Bed ditandai dengan kontak erosional antara batulempung penyusun Formasi Brown Shale dengan batupasir penyusun Formasi Upper Red Bed. Dari data log menunjukkan Formasi Brown Shale terutama tersusun oleh sedimen detritus halus yaitu perselingan antara batulempung dan batulanau. Adanya perselingan batulempung dan batulanau diindikasikan dengan rekaman kurva gamma ray yang membentuk pola gergaji. Fenomena tersebut menunjukkan bahwa batuan penyusun formasi ini mempunyai sifat yang rapuh (brittle). Sifat kerapuhan merupakan salah satu sifat yang dibutuhkan oleh suatu batuan untuk menjadi reservoar shale hydrocarbon.

Dari hasil overlay antara kurva sonik dan resistivitas dengan menggunakan Metoda Passey menunjukkan tidak semua interval penyusun Formasi Brown Shale dalam Sumur Kilo membentuk separasi. Kenampakan separasi hanya bisa diamati pada interval $8460-8076 \mathrm{ft}$. Hal ini mengindikasikan bahwa litologi penyusun formasi hanya bagian atas saja yang mempunyai kandungan material organik yang tinggi dan telah mencapai kematangan termal (Gambar 7). Puncak kematangan minyak Formasi Brown Shale pada Sumur Kilo diperkirakan tercapai pada kedalaman $8100 \mathrm{ft}$. Analisis kandungan TOC pada Formasi Brown Shale di Sumur Kilo menunjukkan formasi tersebut mempunyai kandungan organik yang miskin - kaya (0-9\%) (Gambar 7).

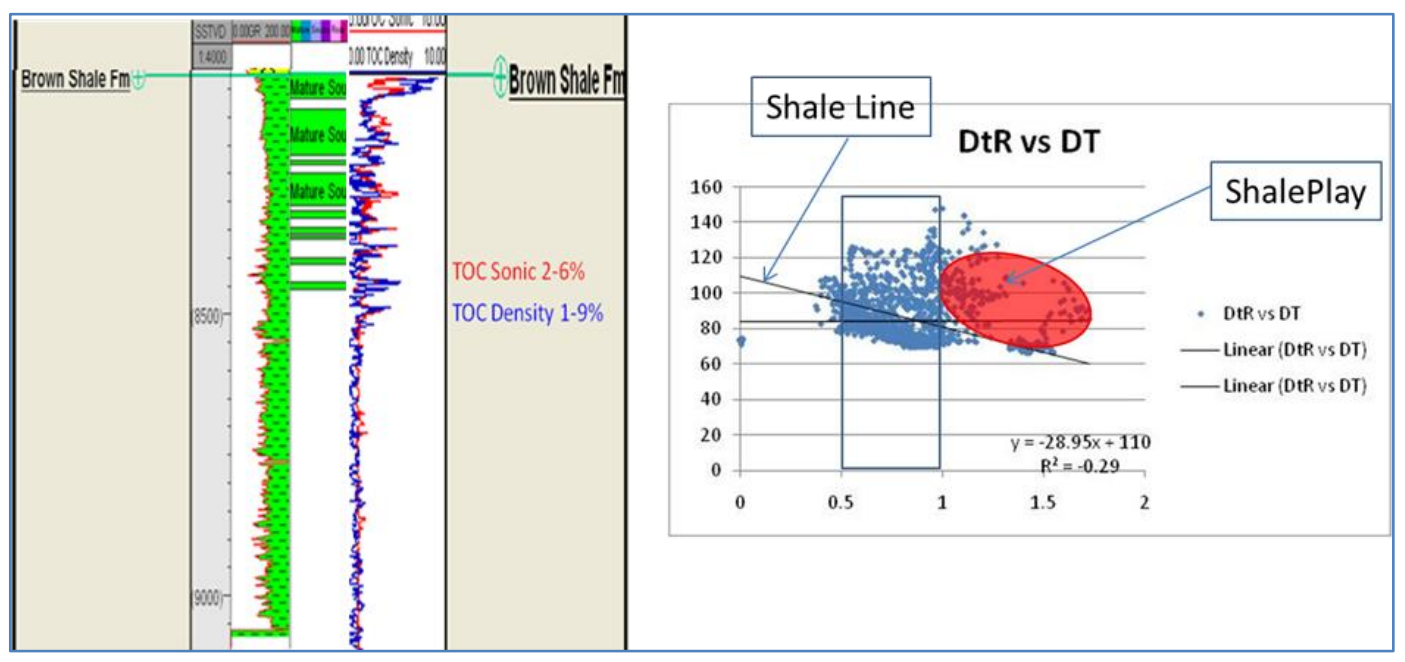

Gambar 7. Hasil Analisis Geokimia Sumur Kilo yang Menunjukan Bagian Atas Formasi Brown Shale Tersusun oleh Litologi yang Kaya Material Organik (TOC 1-9\%) yang Telah Matang 


\section{POTENSI SHALE HYDROCARBON FORMASI BROWN SHALE, CEKUNGAN SUMATRA TENGAH BERDASARKAN DATA LOG MEKANIK}

Keberadaan serpih organik yang matang pada Formasi Brown Shale dalam Sumur Kilo juga diperkuat dari hasil analisis dengn Metoda Bowman (2010). Hasil cross-plotting antara harga $\log$ sonik semu (DtR) dengan kurva log sonik (DT) menunjukkan adanya zona prospek (shale play) pada formasi ini (Gambar 7).

Dari uraian di atas dapat disimpulkan bahwa hanya bagian atas interval penyusun Formasi Brown Shale dalam Sumur Kilo yang mempunyai potensi baik sebagai batuan induk migas maupun reservoar shale hydrocarbon.

\section{Kesimpulan}

Berdasarkan hasil analisis seperti yang telah diuraikan, dapat disimpulkan sebagai berikut :

1. Formasi Brown Shale pada semua sumur telitian tersusun oleh perselingan batulempung dengan batulanau yang bisa membentuk suatu formasi yang bersifat rapuh, sehingga mempunyai potensi yang baik sebagai reservoar shale hydrocarbon.

2. Seluruh interval Formasi Brown Shale dalam Sumur Gamma mempunyai potensi sebagai batuan induk yang kaya dan telah mencapai tingkat kematangan termal (mature source rock).

3. Hanya interval bagian atas Formasi Brown Shale dalam Sumur Jeta dan Kilo yang mempunyai potensi sebagai batuan induk migas.

\section{DAFTAR PUSTAKA}

Adi Harsono, 1992, Interpretasi dan Aplikasi Log, Schlumberger Educational Services,Jakarta.

- Asquith, G.B. \& Gibson, C.R., 1982, Basic Well Log Analysis for Geologists, AAPG,Oklahoma.

Bowman, T, 2010, Direct Method for Determining Organic Shale Potential from Porosity and Resistivity Logs to Identify PO\ossible Resource Plays, AAPG Annual Convention and Exhibition, New Orlean.

Dewan, J.T., 1983, Essentials of Modern OpenHole Log Interpretation, Penn Well Books Co.Oklahoma.

Heidrick, T.L., \& Aulia, K., 1993. A Structural and Tectonic Model of The Coastal Plains Block, Central Sumatra Basin, Indonesia. Proc., Indon. Petr. Assoc., 22st Ann. Conv., v. 1, p. $285-317$.

Passey, Q.R. S. Creaney, J.B. Kulla, F.J. Moretti and J.D. Stroud, 1990, A Practical Model for Organic Richness from Porosity and Resistivity Logs, AAPG Bull., Vol. 74, Hal. 1777-1794. 